\title{
Perbincangan Orientalisme Melalui Analisis Semiotika dalam Animasi
}

\author{
IZRA INNA BINTI MD IDRIS \\ MOHAMAD SALEEH RAHAMAD \\ MD AZALANSHAH MD SYED \\ Universiti Malaya
}

\begin{abstract}
ABSTRAK
Kajian ini menyingkap, menginterpretasi dan memahami pengaruh orientalis dalam siri animasi Saladin: The Animated Series melalui analisis semiotik Roland Barthes. Elemen semiotik ini dapat dilihat dalam kerangka semiotik daripada Barthes dengan memecahkan tanda kepada dua komponen, iaitu signifier dan signified. Sistem tanda ini digunakan untuk melihat pemaparan simbol melalui bingkai atau frame dalam animasi ini. Analisis kajian ini meneliti perubahan siri animasi ini daripada tajuk, poster, penggunaan bahasa, yang menghasilkan wacana orientalisme untuk merendahkan tokoh Islam, Salahuddin al-Ayubi. Dapatan kajian mendapati nama tokoh Islam yang dijadikan tajuk siri animasi ini mengambil nama panggilan orang Barat, Saladin dan bukannya Salahuddin al-Ayubi. Seterusnya, berlaku perubahan dalam pemaparan tokoh Islam dalam poster filem animasi Saladin ke siri animasi Saladin: The Animated Series. Berlaku kekeliruan apabila wajah Saladin, hero siri animasi ini tidak diletakkan di tengah poster. Perubahan pemaparan tokoh Islam dalam setiap poster tersebut menunjukkan berlakunya pengaruh orientalisme. Dari segi penggunaan bahasa pula, kajian ini menganalisis dialog sebagai petanda dan siri animasi ini menunjukkan penerimaan unsur pengaruh luar seperti penggunaan bahasa Inggeris sebagai bahasa utama, alih bahasa dalam bahasa Arab dilakukan untuk penonton di Timur Tengah, dan bahasa Melayu hanya diletakkan sebagai subtitle atau sari kata. Hasil penelitian menunjukkan bahawa orientalisme mencalarkan identiti tokoh Islam ini.
\end{abstract}

Kata kunci: Orientalisme, semiotik, sistem tanda, penanda (signifier), petanda (signified).

\section{Discussion of Orientalism through Semiotic Analysis in animation}

\begin{abstract}
This study reveals, interprets and understands the oriental influence in Saladin: The Animated Series through the semiotic analysis of Roland Barthes. This study looks at the semiotic elements found in the animated series through a system of signs and this conceptual framework of Barthes is divided into two components, signifier and signified. This sign system is used to look at the symbols through frames in this animation. The analysis of this study examines the changes in the title, poster, use of language, which led to the occurrence of orientalism discourse to disgrace the Islamic figure, Salahuddin al-Ayubi. The findings of the study found that the Westerners used Saladin as a title and not Salahuddin al-Ayubi. Next, the changes in the portrayal of Islamic figure in the poster of the animated film Saladin and Saladin: The Animated Series. There was confusion when the main character of this animated series, Saladin, was not placed in the middle of the poster. Each of the posters shows the influence of orientalism. In terms of language use, the animated series shows the acceptance of external influences such as the use of English as the primary language. The Arabic language is used for the audience in the Middle East and the Malay language is positioned only as a subtitle. The results show that orientalism tarnishes the identity of this Islamic figure.
\end{abstract}

Keywords: Orientalism, semiotic, sign system, signifier, signified. 


\section{PENDAHULUAN}

Wacana orientalisme merupakan suatu kekuatan fikiran yang membezakan ontologis dan epistemologis antara Timur dengan Barat yang dibawa oleh orientalis melalui media animasi. Edward Said (1978, hlm. 86) dalam buku Orientalism memaparkan dikotomi Barat dan Timur dalam dua perkara, iaitu (1) pengukuhan identiti Barat dan pertahanan, perluasan hegemoni Barat terhadap bangsa Timur. (2) Orientalis menyediakan ruang untuk mengendalikan Timur.

Menurut Pamela Nilan dalam artikel "Muslim Media and Youth in Globalizing Southeast Asia", siri animasi Saladin: The Animated Series ialah percubaan Malaysia untuk mengeksport produk media berorientasikan visual Islam. Sasaran penonton ialah kanakkanak Islam di seluruh dunia yang berumur dalam lingkungan 10 hingga 12 tahun. Siri ini turut memaparkan aksi perang epik untuk menarik minat kanak-kanak Islam, khususnya (Nilan, 2008, hlm. 45-58).

Menurut Nilan (2008, hlm. 45), Saladin ialah Salahuddin atau nama sebenarnya, Salah al-Din Yusuf Ibn Ayyub yang merupakan pemimpin dan pejuang Islam yang telah membawa keluar tentera Kristian dari Palestin pada zaman perang Salib dan menyatukan dunia Islam. Perang Salib telah mengambil masa selama 88 tahun, dan pihak Islam memenangi kembali Palestin ke tangan mereka. Ini menjadikan Salahuddin al-Ayubi seorang tokoh Islam yang penting pada ketika itu. Laman web Saladin juga menggunakan slogan yang sama: "Saladin pada zaman kegelapan manusia, beliau adalah sumber harapan manusia", dan 'manusia' di sini menurut Nilan merupakan masyarakat Muslim.

Terdapat 26 episod Saladin: The Animated Series, dan dipasarkan di Indonesia, India, Pakistan, Turki, Timur Tengah, Afrika Utara, China, dan Barat. Nilan (2008, hlm. 47) membuat sintesis bahawa teks Saladin melambangkan de-traditionalization atau membuang tradisi lama dan re-traditionalization atau mencipta tradisi baharu dalam pengeluaran media Islam Asia Tenggara. Saladin: The Animated Series juga menggunakan proses teknologi tinggi 3Digital, atau 3D yang kontemporari dan popular untuk membentuk zaman kegemilangan Islam pada masa lalu.

Tujuan produk Media Islam ini adalah sama seperti produk media yang lain, iaitu sasaran produk khususnya untuk kanak-kanak Islam di seluruh dunia. Oleh sebab sasarannya untuk kanak-kanak, maka watak Saladin telah diubah dan digambarkan sebagai wira berbentuk komedi dan kebanyakan unsur sejarah dalam kehidupan pahlawan Islam Salahuddin al-Ayubi diketepikan. Watak Saladin dalam Saladin: The Animated Series digambarkan sebagai wira yang berani menghadapi bahaya, tidak mengaku kalah, dan lucu (Siri animasi Saladin di TV1 setiap Sabtu, 2010). Seterusnya, terdapat unsur lain seperti penjahat, pertempuran yang melibatkan penggunaan pedang, dan drama percintaan.

Setelah dua siri rintis yang pertama ditayangkan di saluran di TV1 pada tahun 2007, terdapat beberapa komen daripada blog yang mengkritik Saladin: The Animated Series kerana kandungannya bertentangan dengan keperibadian tokoh Islam Sultan Salahuddin al-Ayubi dan pembikinan animasi yang tidak setara dengan kos yang telah dikeluarkan oleh kerajaan Malaysia (Saladin Convoy, 2008). Disebabkan kritikan yang diberikan terhadap siri animasi ini, pihak produksi telah membuat penukaran pada bahagian teknikal seperti penambahbaikan wajah watak dan sedikit perubahan jalan cerita berbanding yang asal. Namun begitu, pihak produksi masih mengekalkan jalan cerita yang menyelewengkan biografi Sultan Salahuddin al-Ayubi.

Antara kritikan dalam media sosial yang diberikan terhadap Saladin: The Animated Series oleh masyarakat, pertama dalam blog Saladin Convoy (2008) yang tidak bersetuju terhadap Saladin: The Animated Series kerana kandungannya yang bertentangan dengan 
keperibadian Salahuddin al-Ayubi. Penulis blog telah memberikan kritikan daripada satu siri rintis kepada siri rintis yang lain serta mengetengahkan penampilan watak-watak utama. Menurut penulis, Saladin: The Animated Series terlalu mengikut acuan filem animasi Disney, bermula dengan wajah Saladin, penampilan sahabatnya Tarik, teman wanita Saladin, Anisa, yang berperanan sebagai pencuri, watak-watak antagonis serta jalan cerita yang tidak lari daripada acuan Disney. Terdapat 32 komen, dan rata-rata bersependapat dengan penulis blog ini (Saladin Convoy, 2008).

Seterusnya, media sosial (Facebook) 'Betulkan Balik Fakta Animasi Saladin' telah diwujudkan pada 2011 yang juga mengkritik Saladin: The Animated Series. Tujuan media sosial ini dilancarkan dengan seramai 1,279 (setakat 15 Ogos 2016) adalah bagi menyuarakan rasa tidak puas hati terhadap siri ini. Antara sebab kritikannya ialah tokoh Islam yang digambarkan langsung tidak seperti Sultan Salahuddin al-Ayubi. Siri animasi Saladin: The Animated Series disifatkan sebagai menghina keperibadian tokoh serta merosakkan akhlak dan nilai akidah dan ajaran Islam itu sendiri. Penulis media sosial ini mengharapkan agar siri animasi ini ditukar tajuknya supaya tidak mengelirukan golongan muda Islam di Asia (Betulkan Balik Fakta Animasi Saladin, 2011).

\section{Kajian Orientalism}

\section{KAJIAN LITERATUR}

Orientalisme ialah dua gabungan perkataan, iaitu orient dan isme. Orient merupakan perkataan yang berasal daripada bahasa Perancis manakala isme pula ialah perkataan yang berasal daripada Belanda, dan gabungan dua perkataan ini membentuk perkataan orientalisme yang membawa maksud suatu fahaman, aliran, atau amalan (Engku Ahmad Zaki, 2017, hlm. 67). Menurut fahaman Islam, orientalisme atau al-Istisyraq ialah ilmu Timur atau ilmu yang berhubung dengan dunia Timur. Orientalis atau mustasyriq pula merujuk kepada orang Barat yang mengkaji ilmu Timur sehingga mereka menjadi pakar, contohnya dalam bidang bahasa Arab, sehingga mereka mampu mentafsir al-Quran dan hadis. Secara umumnya, orientalisme ialah kajian Barat terhadap Islam dalam bidang bahasa, sastera, sejarah, akidah, syariah, dan tamadun (Mahmud Hamdi Zaqzuq, Mudasir Rosder, \& Che Yusoff, 1989, hlm. 1-2).

Said (1978, hlm. 1-4) pula menyatakan bahawa Orientalisme merupakan satu kaedah untuk memahami dunia Timur berdasarkan pengamatan masyarakat Barat. Said menerangkan tiga perkara yang saling berkaitan, iaitu pertama, Orientalis merupakan orang yang mengajar, menulis sebuah karya, atau melakukan penyelidikan dunia Timur; kedua ialah kaedah pemikiran Orientalisme yang berdasarkan perbezaan antara dunia Timur dengan Barat; ketiga, Orientalisme merupakan kaedah orang Barat untuk mendominasi, menyusun semula dan menguasai Timur dan mencipta kenyataan mengenai dunia Timur khususnya berkaitan agama, mengajari dan menguasai dunia Timur serta mengubah mengikut kehendak mereka (Said, 1978, hlm. 1-4).

Edward Said, dalam buku Orientalism: Western conceptions of the Orient (1978) menyatakan bahawa Orientalisme ialah cara orang Barat "mentimurkan Timur" (Said, 1978, $\mathrm{hlm}$. 1). Barat ingin mendominasi Timur untuk menguatkan pengaruh Barat ke atas Timur. Said menyatakan bahawa Orientalisme juga bermaksud memahami dunia Timur menurut cara pandang dan pengalaman orang-orang Eropah. Menurut Said lagi, Orientalisme ialah sistem yang telah diatur secara sistematik oleh Barat untuk mencipta Timur sebagaimana yang dikehendaki oleh Barat dari segi sosiologi, politik, ekonomi, ketenteraan dan imaginasi. 
Pengalaman Eropah Barat perlu diserap masuk ke dunia Timur supaya tiada perbezaan dari segi imej, idea, personaliti dan pengalaman (Said, 1978, hlm. 1).

Edward Said turut mengkritik hegemoni Barat terhadap Timur. Menurut Said, masyarakat yang terjajah (Timur) akan meniru penjajahnya dalam penampilan dan penilaian hidup sehari-hari. Pihak penjajah (Barat) melakukan eksploitasi melalui pelbagai sistem seperti ekonomi dan politik, sehinggalah penjajahan dalam bentuk pengetahuan (Said, 2001, $\mathrm{hlm}$. 113). Terdapat pelbagai penggunaan taktik penjajahan secara halus ini dalam media, tulisan, filem, iklan, brosur, gambar dan media lainnya (Said, 2001, hlm. 7). Dasar Orientalisme adalah untuk memutarbelitkan fakta, menjauhkan umat Islam dengan kitab suci mereka, iaitu al-Quran (Mohd Fikri, 2011, hlm. 48).

Dalam siri Perang Salib (the Crusade) yang berakhir dengan kekalahan Barat, pihak Barat menyatakan bahawa mereka tidak mungkin menang dengan cara peperangan dengan tentera Islam. Akibat malu dengan kekalahan, Barat merancang siri peperangan yang lebih halus, iaitu 'perang saraf'. Neokolonialisme ialah amalan geopolitik menggunakan kapitalisme, globalisasi perniagaan, dan imperialisme budaya (Sartre, 2001, hlm. 1-3) bagi tujuan mempengaruhi negara dan juga merupakan salah satu bentuk perang saraf yang dirancang oleh Barat. Menurut Said, "...the Orient nor upon a clearly delimited set of texts, authors, and ideas that together make up the Orientalist canon" (Said, 1978, hlm. 4). Antara cara pembentukan orientalis ialah menghalang teks, penulis, dan idea, sebaliknya mengarah penulisan yang membentuk pemikiran orientalis.

Antara pendekatan yang digunakan oleh orientalis ialah meracuni pemikiran umat Islam agar tidak berpegang pada ajaran Islam. Perkara pertama yang dilakukan ialah memutarbelitkan sejarah dan tamadun Islam melalui penulisan dan kajian sehingga berjaya melahirkan buku pengajian Islam dengan pelbagai fakta yang menyeleweng dan kemudiannya diguna pakai oleh orang Islam sendiri. Fakta sirah hidup Nabi Muhammad SAW, tokoh-tokoh Islam, dan sejarah Islam telah diseleweng dengan fakta yang salah (Mohd Farhan, 2014, hlm. 22-24). Sebahagian fakta telah diputarbelitkan dan disisipi kisah mitos sehingga kisah tersebut menjadi suatu cerita yang baharu dan sukar dikenal pasti kesahihannya.

\section{Kajian Semiotik}

Umumnya, semiotik ialah kajian sistem tanda dalam suatu konteks senario, gambar, teks, adegan dalam filem, dan dalam konteks kajian ini frame atau bingkai yang diambil daripada snapshot dan bingkai (frame) animasi yang dapat dinilai dan diberi makna. Semiotik berasal daripada perkataan Greek, iaitu Semeion yang membawa maksud tanda atau sign dalam sistem perlambangan (Saussure, 1986:24). Seterusnya, Charles Sander Peirce menjelaskan bahawa tidak ada tanda kecuali ditafsirkan sebagai tanda, nothing is a sign unless it is interpreted as a sign (Pierce, 1931, yang dipetik dalam Chandler, 2002, hlm. 17).

Saussure mendefinisikan semiologi sebagai mengkaji tanda-tanda kehidupan dalam masyarakat, dan tujuannya untuk menunjukkan bagaimana terbentuknya tanda-tanda serta kaedah yang digunakan (Sobur, 2006, hlm. 12). Sementara itu, istilah semiotik oleh Pierce pula merujuk kepada doktrin formal tentang tanda-tanda yang terbahagi kepada tiga bahagian, iaitu ikon, indeks, dan simbol. Ikon merupakan tanda yang sama antara penanda dan petanda yang didapati secara langsung. Indeks pula ialah tanda yang mewakili sebab dan akibat kepada kenyataan. Simbol ialah tanda yang mempunyai makna tersirat dan disampaikan secara tidak langsung (Sobur, 2006, hlm. 12-13).

Semiotika atau semiologi dalam istilah Barthes ialah memahami kemanusiaan (humanity), mendefinisikan hal (things), untuk menandakan (to signify), dan untuk 
berkomunikasi (to communicate). Makna di sebalik objek pula ialah berlakunya komunikasi terhadap objek tersebut, dan ini membawa kepada sistem tanda. Seterusnya, tanda (signs) ialah dasar bagi komunikasi secara keseluruhannya. Suatu tanda menandakan perkara selain dirinya; makna (meaning) pula ialah hubungan antara satu objek atau idea dengan suatu tanda (Barthes, 1988, hlm. 179).

Seterusnya, teori Saussure menekankan bahawa bahasa adalah sistem tanda, dan sistem tanda ini dibahagikan kepada dua komponen, iaitu signifier dan signified (Saussure, 1986). Signifier atau penanda merujuk kepada imej, objek, dan bunyi manakala signified ialah petanda yang memberi gambaran kepada imej, objek, atau bunyi. Semiotik membawa pemahaman terhadap tanda dan makna, melalui perkataan, imej, dan kelakuan. Semiotik juga berkaitan dengan meaning-making dan representasi yang jelas dapat dilihat dalam dalam bentuk teks dan media (Chandler, 2002, hlm. 2)

Saussure dan Barthes mengambil bahasa sebagai semiotik dengan makna tersirat, iaitu merujuk kepada budaya, sosial, dan pendidikan. Oleh itu, pendekatan semiotik dalam budaya juga terungkap dalam bahasa sehingga menyebabkan masyarakat mampu memahami cara hidup yang dilalui (Mana Sikana, 2013). Misalnya, pelakon utama ialah penanda, dialog daripada skrip yang dihasilkan ialah petanda, iaitu terdapat makna tersirat di sebalik dialog yang disampaikan. Metz (1995) melakukan kajian terhadap simbol dan tanda dalam filem. Metz mengambil shot dalam filem dan menganalisis dan menghuraikan makna yang khusus terhadap gambar daripada shot tersebut.

Penelitian ini menganalisis teks menggunakan metode semiotik Barthes terhadap gambar poster, frame daripada animasi. Dalam menganalisis teks tersebut, pengkaji memilih unsur penanda-petanda-tanda dalam dua sistem makna, iaitu bahagian denotatif dan konotatif. Semiotika Barthes dalam Jadual 1:

Jadual 1: Peta Tanda Roland Barthes (Sobur, 2006, hlm. 123)

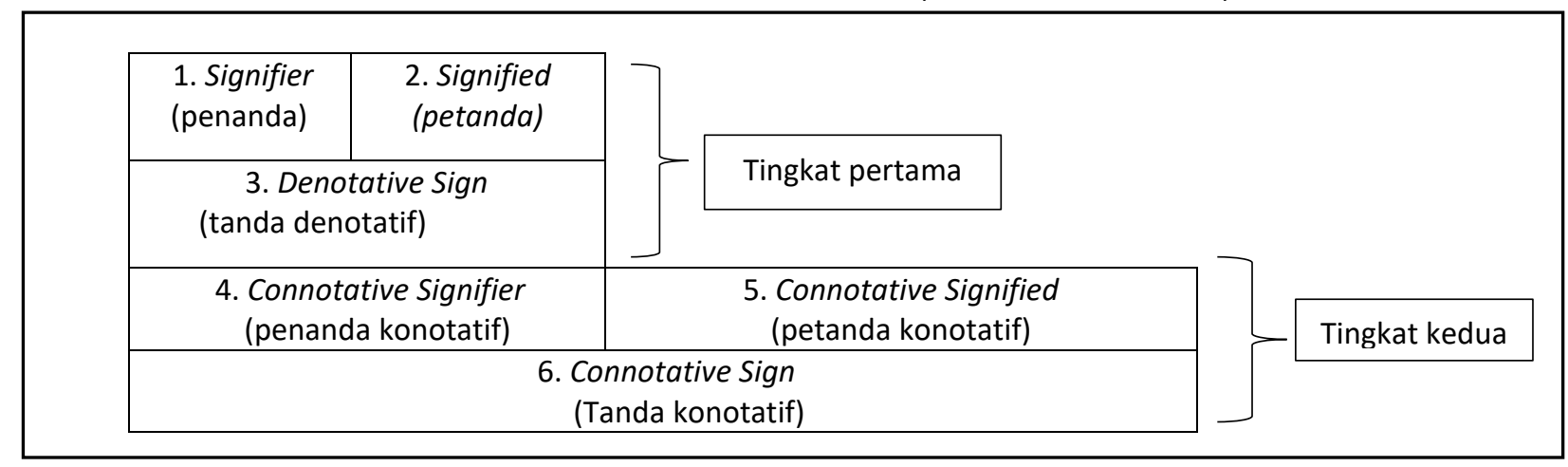

Terdapat dua proses signifikasi dalam peta analisis Barthes. Tahap pertama ialah tanda denotatif yang terdiri atas penanda dan petanda. Pada tahap kedua, tanda denotatif juga penanda konotatif. Konotasi pula dapat dibezakan daripada denotasi melalui kaedah yang digambarkan dan konotasi gambar atau frame yang diambil. 


\section{Sorotan Kajian}

Dalam kajian 'Analisis Semiotik Watak dalam Filem Terbaik dari Langit' oleh M Fazmi, Zairul Anuar dan Imelda Ann (2019), pengkaji menganalisis sistem tanda dan penanda dalam watak dan perwatakan filem Terbaik dari Langit (2014). Dalam konteks penelitian, filem merupakan sebuah teks yang tersusun yang memudahkan sistem penanda dan petanda. Pengkaji menggunakan teori Roland Barthes untuk mengembangkan sistem tanda Pierce, iaitu dua tahap signifikasi penanda dan petanda kepada denotasi, konotasi, dan mitos. Secara ringkas, denotasi ialah gambar, visual, atau imej dan konotasi pula ialah maknanya. Pengkaji merumuskan konstruksi makna dalam filem pilihan dihubungkan dengan analisis watak dan semiotik. Pengkaji memilih adegan-adegan pada watak untuk mendapat sistem tanda.

Filem memaparkan naratif hubungan sosial dan budaya yang melibatkan masyarakat tertentu yang disampaikan melalui sistem tanda dan makna. Penggunaan elemen mise en scene, latar, watak, props, kostum dan pengcahayaan memainkan peranan penting selain aspek verbal, iaitu dialog. Pengkaji melihat makna melalui sistem teori dua tahap signifikasi, iaitu denotasi dan konotasi yang terdapat dalam adegan filem Terbaik dari Langit (TDL) dengan melihat sisi sinematik dan semiotik filem.

Model teori semiotik oleh Roland Barthes digunakan untuk membina sistem tanda dalam filem TDL. Pengkaji memilih watak-watak yang mempunyai hubungan dengan budaya dan sosial masyarakat. Dalam konteks filem TDL, isi cerita filem ini berkisar kepada industri perfileman Malaysia. Pengkaji memilih watak-watak seperti Berg, Pengkritik filem, ljam, Ali, Toyu, Pakcik Lori, dan Datuk sebagai subjek perkaitan makna atau penanda dan petanda. Pengkaji mengeluarkan adegan daripada watak dan keterangan adegan, seterusnya dialog adegan disertakan. Kemudiannya, pengkaji menerangkan adegan dari sudut teori two orders of signification oleh Barthes; contohnya, pengarah melahirkan watak Berg yang menggambarkan kualiti pelakon, dunia glamor, dan tekanan permintaan oleh penonton. Kesimpulannya, semiotik watak ini mampu mengangkat naratif sesebuah filem.

Kajian yang seterusnya bertajuk "Simbolisme watak dan perwatakan berdasarkan konteks sosio-budaya masyarakat Malaysia dalam filem Ola Bola" (2016) oleh Nor Ain dan Zairul Anuar (2016). Kajian ini menggunakan kaedah kualitatif, iaitu teknik analisis yang fokus kepada watak dalam filem Ola Bola (2016). Kajian ini menganalisis simbol watak dan perwatakan yang menjadi representasi sosiobudaya untuk menyampaikan mesej dan makna kepada masyarakat Malaysia melalui filem ini. Watak dan perwatakan dalam filem ini mewakili masyarakat Malaysia yang berbilang kaum. Kajian ini menggunakan konsep semiotik Ferdinand De Saussure untuk menilai pemaparan watak dan perwatakan, dan simbol sosiobudaya.

Filem Ola Bola (2016) telah diarahkan oleh Chiu Keng Guan yang mengisahkan seorang wartawan yang ditugaskan untuk membuat kajian mengenai pasukan bola sepak Malaysia era 80-an. Filem ini telah mengambil peristiwa yang berlaku sebelum kejohanan Sukan Olimpik Moscow 1980 yang melihat Malaysia memboikot kejohanan kerana membantah serangan di Afghanistan. Teori Semiotik digunakan dengan melihat penanda (signifier) dan petanda (signified) yang mengambil syot dalam filem tersebut sebagai penanda dan menganalisis dialog sebagai petanda dengan melihat mesej yang disampaikan.

Dapatan kajian memaparkan kepentingan hubungan antara kaum, perpaduan, persahabatan dan pengorbanan yang dilahirkan oleh watak dan perwatakan. Mesej disampaikan melalui pengucapan dialog dan perlakuan watak mengenai kepentingan agama dan penggunaan bahasa ibunda seperti bahasa Melayu, Cina, dan Tamil. Filem ini memaparkan penerimaan pengaruh unsur luar seperti penggunaan bahasa Inggeris dalam 
kehidupan seharian masyarakat Malaysia. Dalam filem ini simbol merupakan elemen naratif yang membentuk penceritaan. Watak dan perwatakan juga dikaitkan dengan elemen naratif yang lain seperti latar tempat, masa, dan plot. Kesimpulannya, watak dan perwatakan dalam filem Ola Bola (2016) dibentuk berdasarkan sosiobudaya masyarakat Malaysia seperti perpaduan kaum.

\section{METODOLOGI KAJIAN}

Kajian ini menggunakan kaedah kualitatif Semiotik oleh Barthes melalui teknik penanda (signifier) dan petanda (signified) dalam menginterpretasi siri animasi Saladin: The animated series. Huraian sistem tanda ini dibuat dengan melihat wacana orientalisme yang diserap masuk dalam siri ini. Dengan teori semiotik, makna dapat dibaca dengan lebih sistematik. Kajian ini melihat makna melalui tajuk, poster, dan bahasa, dalam siri animasi Saladin: The animated series dengan melihat penyampaian makna menerusi tiga petanda tersebut.

Dalam kajian ini, watak Saladin dalam Saladin: The animated series memaparkan tokoh Islam Salahuddin al-Ayubi dipergunakan secara simbolik oleh pengarah Steve Bristow yang membawa pengaruh orientalis dalam animasi ini. Penelitian telah dilakukan dalam kajian ini untuk mengeluarkan frame atau bingkai dengan menggunakan snapshot daripada animasi Saladin: The animated series (untuk dijadikan penanda (signifier) dan penerangan petanda (signified) dibuat dengan meneliti pendekatan orientalisme.

\section{DAPATAN KAJIAN DAN PERBINCANGAN}

Sinopsis Saladin: The Animated Series (2010)

Saladin: The Animated Series (2010) dikeluarkan oleh Perbadanan Pembangunan Multimedia atau Multimedia Development Corporation (MDeC) dan Kementerian Sains, Teknologi dan Inovasi, Malaysia (MSC), iaitu badan kerajaan Malaysia. Pada awal penyiaran Saladin: The Animated Series pada 2010, Bristow menyatakan di laman sesawang:

Saladin is an animated project inspired by the life of Salah Al-Din Yusuf Ibni Ayyub, the Islamic hero who united Muslims in the holy war against the Crusaders in the 12th century.

(Bristow, September 2010).

Saladin merupakan projek siri animasi yang diilhamkan daripada kehidupan Salah al-Din Yusuf Ibni Ayyub, wira Islam yang telah menyatukan umat Islam dalam perang menentang tentera Salib pada abad ke-12 (Bristow, 2010).

Sebilangan umat Islam di Malaysia sedar akan kesalahan fakta yang ditonjolkan dalam siri animasi Saladin: The Animated Series ini. Serangan peribadi yang mencemarkan imej tokoh Islam yang terbilang ini telah membangkitkan rasa ketidakpuasan hati mereka lalu mereka meluahkannya dalam blog dan Facebook 'Betulkan Balik Fakta Animasi Saladin' pada 15 Februari 2011 (Betulkan Balik Fakta Animasi Saladin, 2011). Untuk meredakan kemarahan masyarakat Islam Malaysia pada ketika itu, pihak penerbitan Saladin: The Animated Series memuat naik kenyataan di laman sesawang mereka pada Mei 21, 2011:

Please note that this is NOT the story of Salahuddin al-Ayubi. This is an entertaining series for children with the character Saladin, which has NOTHING to do with the Legend of Islam Salahuddin al-Ayubi (May 21, 2011). 
Harap maklum bahawa ini BUKAN kisah Salahuddin al-Ayubi. Ini adalah siri hiburan untuk kanak-kanak dan watak Saladin dalam siri ini, TIDAK ADA kenamengena dengan legenda Islam Salahuddin al-Ayubi (Mei 21, 2011).

(Diambil daripada laman sesawang Saladin.com.my).

Seterusnya pada November 24, 2014, laman sesawang Saladin sekali lagi memuat naik maklum balas sejarah biografi tokoh ini. Berikut adalah siri fiksyen yang diilhamkan dari watak Saladin. la tiada mempunyai kaitan dengan sejarah sebenar. Sebarang persamaan watak atau keadaan adalah kebetulan semata-mata (Saladin, Nov 24, 2014).

Kenyataan awal yang dimuat naik oleh pihak produksi bertentangan dengan kenyataan yang dibuat pada tahun berikutnya. Ini disebabkan pihak produksi ingin menutup kesalahan mereka kerana telah menggunakan tokoh Islam Salahuddin al-Ayubi. Pihak produksi menutup kesalahan mereka di sebalik perkataan 'fiksyen' dengan menyatakan bahawa animasi ini bukan kisah Salahuddin dan tiada kena-mengena dengan tokoh legenda Islam Salahuddin. Maka, apakah tujuan pihak produksi memilih tokoh Islam ini sebagai watak utama dalam siri animasi Saladin: The Animated Series. Inilah pekerjaan yang dilakukan oleh pihak orientalis apabila mereka mengetahui bahawa masyarakat Islam Malaysia sudah menyedari penyelewengan mereka. Mereka berselindung disebalik kenyataan "la tiada mempunyai kaitan dengan sejarah sebenar. Sebarang persamaan watak atau keadaan adalah kebetulan semata-mata".

Menerusi animasi Saladin: The Animated Series, fokus kandungan cerita menjurus untuk kanak-kanak. Apa-apa sahaja yang dihidangkan untuk kanak-kanak, bakal diambil, dimamah, diperah dan disalurkan ke dalam minda dan kekal dalam minda mereka selama maklumat ini boleh bertahan. Bagi pihak penerbitan, siri animasi Saladin: The Animated Series dibuat khas untuk kanak-kanak yang berusia 10 tahun sehingga 14 tahun, namun apabila diamati, siri animasi ini memberikan gambaran yang kurang baik terhadap perkembangan kanak-kanak dalam mempelajari tokoh Islam ini. Ini kerana perubahan dalam konteks sejarah dan pemaparan tokoh Islam yang telah dilakukan oleh pihak produksi.

Memahami konteks sebuah sejarah keislaman yang divisualisasikan melalui media animasi seperti siri animasi ini adalah amat diperlukan. Hal ini kerana kanak-kanak Islam perlu diberi pendedahan tentang sejarah tokoh-tokoh Islam yang membawa kejayaan kepada negara-negara Islam. Walau bagaimanapun, konteks cerita, plot, watak, perlulah kepada penelitian sejarah dan peribadi tokoh tersebut.

\section{Analisis Tajuk Saladin: The Animated Series}

Tajuk siri yang dijadikan objek penelitian berjudul Saladin: The Animated Series atau Saladin the Animated Series. Secara keseluruhannya pihak pengarah telah meletakkan nama Saladin sebagai tajuk siri animasi ini. Penggunaan nama Saladin sebagai tajuk siri sudah cukup mengelirukan penonton terutamanya kalangan remaja. Ini disebabkan tajuk siri animasi yang dipilih oleh pihak pengarah dan produksi menjurus ke arah kebaratan. Pihak Barat banyak membuat perubahan nama terhadap tokoh-tokoh Islam dengan tujuan perubahan tersebut dapat mengelirukan orang Islam itu sendiri. Abdul Malik Munip merupakan sejarawan dan bekas pensyarah dari Jabatan Sejarah Universiti Malaya, menyatakan perancangan rapi pihak Barat untuk memastikan dunia keliru berkenaan Islam. Menurut Abdul Malik, kebimbangan Barat ini bermula apabila melihat perubahan masyarakat Arab Jahiliah selepas kedatangan Islam. Mereka mulai sedar bahawa Islam berupaya membawa perubahan kepada masyarakat 
Arab Jahiliah sehingga Islam bangkit membina sebuah tamadun dan peradaban yang tinggi (Abdul Malik Munip, 2003 Julai 29).

Malah, kedatangan Islam merupakan permulaan manusia mengenal ilmu dan meningkatkan nilai ilmu dalam kehidupan. Franz Rosenthal dalam bukunya Knowledge Triumphant menyatakan bahawa kemenangan akan diperoleh melalui peningkatan ilmu (Rosenthal, 2007, hlm. xiii). Rosenthal yang menterjemahkan Muqaddima oleh Ibn Khaldun telah mengenal pasti bahawa pengetahuan sebagai konsep pengukuhan dalam tamadun Islam. Maka, untuk menjadi hebat perlunya penguasaan ilmu oleh orang Barat.

Pihak Barat sedar jika masalah ini tidak dibendung, kemungkinan Islam bakal mencapai tradisi kegemilangan. Strategi pertama yang dilakukan ialah memastikan semua umat Islam sentiasa keliru berkenaan ajaran Islam. Antara langkah yang diambil oleh pihak Barat adalah dengan menukar nama tokoh-tokoh Islam yang banyak menyumbang dalam perkembangan ilmu. Antaranya, Ibnu Sina telah ditukar namanya kepada Avicenna dan Ibn Rusyd telah ditukar namanya kepada Averroes (Abdul Malik Munip, 2003, hlm. 18).

Penukaran nama tempat turut berlaku pada zaman penjajahan. Menurut Edward Said (1978, hlm. 41), antara helah penjajah ialah memperkecil bangsa jajahan selepas berlakunya penaklukan ke atas tanah jajahan. Inggeris dan Perancis telah melakukan penipuan dengan meletakkan bangsa jajahan kepada satu tahap yang buruk untuk mewajarkan mereka dijajahi. Melalui bahasa jajahan, mereka menamakan semula tanah jajahan, antara wilayah yang ditukar nama seperti "Malaya" untuk "Tanah Melayu" dan "India" untuk "Hindia Timur" sesuai dengan keperluan ekonomi yang diperlukan oleh penjajah dan sebagai tanda penguasaan mereka (Edward Said, 1978, hlm. 41; Azhar Wahid, 2011, hlm. 173). Maka, menjadi kebiasaan pihak Barat melakukan penukaran nama tokoh Islam dan juga penukaran nama tempat mengikut kesesuaian mereka.

\section{Analisis Poster Saladin: The Animated Series}

Bagi memahami teks media, tanda-tanda yang terdapat dalam poster perlu diinterpretasikan. Menurut Umberto Eco (1979, hlm. 6-7) diterjemahkan daripada bukunya A Theory of Semiotics menyatakan, "semiotika pada prinsipnya adalah sebuah disiplin yang mempelajari segala sesuatu yang dapat digunakan untuk berdusta". Di bawah tajuk $A$ theory of the lie, tanda itu tidak berdiri secara sendiri dan dalam tanda tersembunyi sesuatu disebaliknya.

Dalam buku Semiotika Komunikasi oleh Wibowo (2013, hlm. 9) memberi contoh poster British Army pada tahun 1990-an, sarat dengan makna apabila gambar warga kulit hitam dan bukan kulit putih diletakkan dalam poster. Poster tersebut memberi tanda dan makna tertentu apabila ditafsirkan. Seterusnya, Sobur (2016, hlm. 13) menyatakan bahawa tanda-tanda pada dasarnya mempelajari kemanusiaan (humanity), dan memahami hal-hal (things), dan memberi makna. Tanda juga membawa informasi bahawa objek-objek itu hendak berkomunikasi dalam sistem berstruktur.

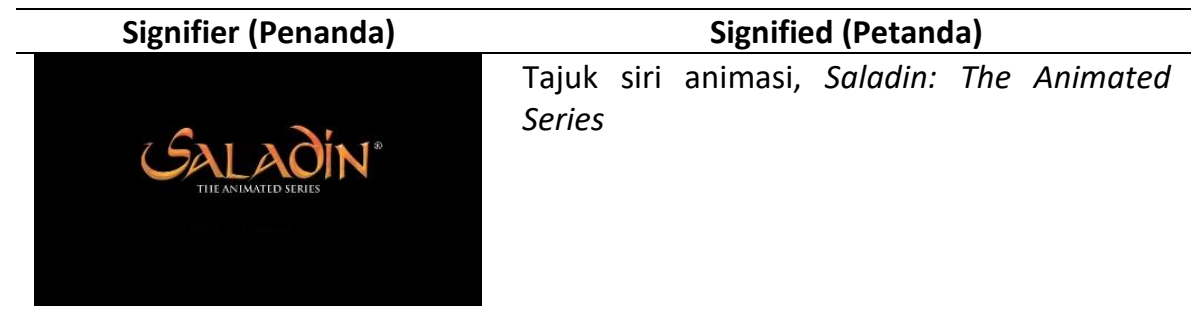

Gambar 1: Tajuk siri animasi, Saladin: The Animated Series 
Frame siri animasi ini telah dijadikan sebagai penanda dan tajuk Saladin: The Animated Series telah dijadikan petanda. Tajuk siri ini telah dibaratkan dengan mengambil sebutan orang Barat, Saladin. Dalam setiap episod Saladin: The Animated Series yang berbahasa Inggeris, dan bahasa Arab, watak Saladin dipanggil Salahaddin dan bukan Saladin. Namun begitu, pihak pengarah dan produksi tetap mahu meletakkan Saladin sebagai tajuk. Konsep distortion atau penyelewengan bertujuan mengelirukan khalayak sasaran siri ini. Khalayak pasaran bagi siri ialah kanak-kanak dalam lingkungan 10 hingga remaja 14 tahun (Nilan, 2008). Pihak pengarah dan produksi ingin menunjukkan bahawa judul Saladin adalah bertepatan dengan konsep Barat yang diketengahkan.

Apabila Saladin: The Animated Series dipertontonkan kepada khalayak umum pada tahun 2008, terdapat blog yang menyangkal pemaparan Saladin sebagai merepresentasi tokoh Islam Salahuddin al-Ayubi (Saladin Convoy, 2008). Maka pada tahun 2012, pihak pengarah dan produksi telah meletakkan 'Siri ini tidak ada kena-mengena dengan tokoh Islam Salahuddin al-Ayubi' pada siri-siri yang dipertontonkan. Pihak pengarahan menyangkal bahawa Saladin: The Animated Series ini bersamaan dengan tokoh Islam Salahuddin al-Ayubi, namun dalam masa yang sama mengekalkan nama tokoh Islam ini. Pernyataan seperti ini bertujuan menyelamatkan dan melindungi diri mereka sendiri.

Signifier (Penanda)
$\begin{aligned} & \text { Theler Saladin yang dijadikan poster pada awal } \\ & \text { pembikinan Saladin } \\ & \text { A historical figure from the Crusades. A team } \\ & \text { of enthusiastic and talented animators. A } \\ & \text { national project. }\end{aligned}$

Gambar 2: Poster dari treler Saladin selama 6:03

Frame treler animasi Saladin ini telah dijadikan sebagai penanda dan petanda treler ini telah dijadikan poster untuk mempromosikan animasi Saladin. Pada awal perbincangan pada tahun 2000, Saladin akan dijadikan sebuah filem animasi. Pembikinan treler Saladin untuk filem animasi tersebut telah siap dipertontonkan pada April 2006. Pihak syarikat Silver Antz mengambil alih pembikinan treler Saladin pada tahun 2005: 'Silver Antz was awarded the contract by our Malaysian Multimedia Development Corporation (MDeC) to produce the trailer for Saladin in 2005'(Silver Antz, 2014).

Silver Antz di laman webnya menyatakan bahawa mereka telah diberi mandat oleh Perbadanan Pembangunan Multimedia (MDeC) untuk menerbitkan treler Saladin pada tahun 2005. Treler yang dijadikan poster inilah yang telah memenangi anugerah dalam Festival Animasi Antarabangsa Tokyo (Tokyo Big Sight Award) dan Anugerah Teknologi Terbaik di Festival Antarabangsa Kartun dan Animasi di Seoul (Seoul International Cartoon and Animation Festival - SICAF) (Hassan Abdul Muthalib, 2008).

Pada bahagian bawah poster tertulis seperti yang berikut: $A$ historical figure from the Crusades. A team of enthusiastic and talented animators. A national project. Kata-kata ini menunjukkan bahawa animasi Saladin mengambil historical figure from the Crusades membawa maksud tokoh sejarah dari perang salib. Pihak produksi telah memilih tokoh sejarah perang salib, iaitu Salahuddin al-Ayubi sebagai watak hero dalam mempromosikan 
animasi ini namun kemudiannya menukar kenyataan dan membuat penolakkan tokoh sejarah ini apabila berlaku kritikan di media sosial.

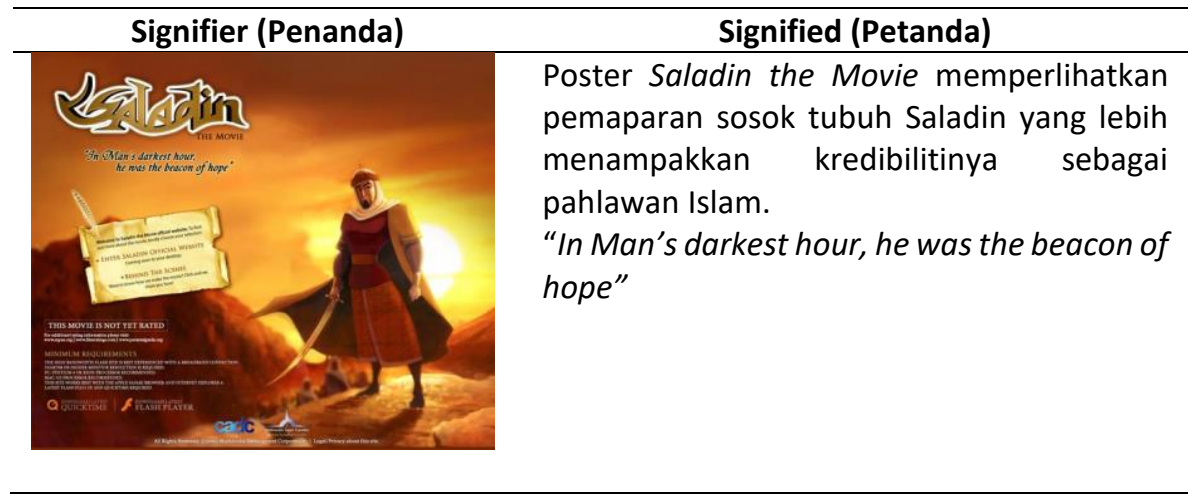

Gambar 3: Poster Saladin the Movie

Gambar 3 menunjukkan poster untuk filem animasi Saladin atau Saladin the Movie yang dijadikan penanda (signifier) dan penerangan poster ialah petanda (signified) yang memaparkan sosok tubuh Saladin yang lebih menyerupai tokoh dan pahlawan Islam. Pemaparan Saladin sebagai hero atau pahlawan Islam lebih jelas kerana pakaian Saladin berserta serban dan berjanggut lebih menunjukkan sifak kepahlawanan tokoh Islam ini.

Pihak produksi meletakkan cogan kata "In Man's darkest hour, he was the beacon of hope" yang membawa maksud pada zaman gelap manusia, dia adalah cahaya harapan. "Dia" di sini merujuk kepada Salahuddin al-Ayubi tokoh pahlawan Islam yang terkenal di zaman pemerintahannya kerana Salahuddin telah berjaya menawan kembali Baitul Maqdis dalam Perang Salib setelah kota itu ditawan oleh tentera Salib (Crusaders) Kristian selama 88 tahun. Kejayaan baginda menawan kembali kota Baitul Maqdis sangat unik kerana tanpa menumpahkan darah dan berjaya menyatukan dunia Muslim keseluruhannya (Ed-Din, 2007; Lane-Poole, 1906; Mohd Roslan \& Nor Shakila, 2012; Izra Inna, Mohammad Saleeh \& Md Azalanshah, 2017).

\begin{tabular}{ll}
\hline Signifier (Penanda) & \multicolumn{1}{c}{ Signified (Petanda) } \\
\hline mester Saladin: The Animated Series (2007) \\
yang diubah oleh pihak pengarah dan \\
produksi.
\end{tabular}

Gambar 4: Poster Saladin: The Animated Series (2007)

Fungsi utama media komunikasi visual ialah menyampaikan maksud tertentu kepada pihak lain, dan salah satu cara penyampaian ialah melalui poster. Poster Saladin: The Animated Series (2007) dalam gambar 4 dijadikan penanda (signifier) dan penerangan poster memperlihatkan pemaparan watak Saladin yang diubah oleh pihak pengarah dan produksi menjadi petanda (signified). Pada 2007 dua siri rintis Saladin Siri Animasi TV telah dipertontonkan sempena Hari Kemerdekaan Malaysia yang ke-50 tahun. 
Dalam Gambar 4, Poster Saladin: The Animated Series (2007) pemaparan watak hero Saladin kelihatan tidak kemas dalam pemakaian serban, tidak memiliki janggut, dan kelihatan agak komersial serta kurang pemaparannya sebagai watak pahlawan Islam. Namun begitu, pihak pengarah dan produksi masih meneruskan pembikinan siri-siri dalam Saladin: The Animated Series dengan penambahbaikan pada aspek teknikal siri tersebut sahaja dan mengekalkan pemaparan Saladin dan persembahan kandungan.

\begin{tabular}{ll}
\hline Signifier (Penanda) & \multicolumn{1}{c}{ Signified (Petanda) } \\
\hline PaldojiN & $\begin{array}{l}\text { Poster Saladin: The Animated Series (2010) } \\
\text { memperlihatkan teknikal animasi 3D yang }\end{array}$ \\
& lebih baik.
\end{tabular}

Gambar 5: Poster Saladin: The Animated Series (2010)

Gambar 5 menunjukkan poster Saladin: The Animated Series (2010) yang dijadikan penanda (signifier) dan penerangan poster ialah petanda (signified) Poster Saladin: The Animated Series yang dikeluarkan pada 2010 mempunyai moto The Hero Who Became a Legend. Siri ini telah diberi penambahbaikan dari segi penggunaan kuda sebagai tunggangan dalam poster tersebut. Paparan Saladin berkuda bertepatan dengan tokoh Salahuddin alAyubi yang berketurunan Kurd dan sememangnya bangsa Kurd terkenal dengan ketangkasan menunggang kuda. Tokoh Islam ini bukan sahaja telah mempelajari menunggang kuda malahan melakukan aktiviti lawan pedang, memanah, dan teknik perang sejak kecil. Kesemua aktiviti ini telah dipelajarinya daripada bapa saudaranya Asad ed-Shirkuh, seorang panglima perang (Syed Alwi, 2015, hlm. 16-17). Teknikal animasi 3D pada poster animasi 2010 memperlihatkan peningkatan namun kandungannya masih mengekalkan penyampaian dan kandungan cerita yang sama.

Pada poster tersebut dinyatakan bahawa siri animasi ini bermula pada 20 November 2010 di RTM1 dan ditayangkan pada setiap hari Sabtu jam 7.30 malam dan ulangannya pada hari Ahad jam 9.30 pagi. Pada poster tersebut terdapat logo MSC (Koridor Raya Multimedia atau Multimedia Super Corridor), MDEC (Perbadanan Ekonomi Digital Malaysia atau Malaysia Digital Economy Corporation), dan JCC (Al Jazeera Children's Channel) kerjasama antara Malaysia dan Qatar.

\begin{tabular}{c} 
Signifier (Penanda) \\
\hline Perubahan yang dilakukan terhadap digital \\
poster Saladin: The AnimatedSeries (2011).
\end{tabular}

Gambar 6: Poster Saladin: The Animated Series (2011) 
Poster Saladin: The Animated Series (2011) dalam Gambar 6 dijadikan penanda (signifier) dan perubahan poster digital ini memaparkan gambar watak Duncan, seorang bekas tentera salib yang menjadi teman kepada Saladin diletakkan di tengah-tengah poster dan watak antagonis diletakkan di hadapan watak protagonist, menjadi petanda (signified).

Penambahbaikan mutu animasi telah dilakukan oleh pihak produksi dari tahun ke tahun. Bagi poster Saladin: The Animated Series terdapat sedikit kekeliruan apabila wajah Duncan diletakkan di tengah poster yang menggambarkan ketokohan seorang hero. Sewajarnya wajah Saladin diletakkan di tengah untuk menampakkan keselarian antara hero dengan tajuk siri. Ini adalah antara permainan pihak produksi dalam menggambarkan ketokohan seorang hero.

Dalam poster Saladin: The Animated Series (2011) pihak produksi mengangkat Duncan, bekas tentera Salib (dalam kisah siri ini) sebagai hero walaupun Duncan bukanlah watak sebenar jika dilihat dari perspektif sejarah pada ketika itu. Watak ini direka oleh pihak produksi untuk membantu, melindungi, mengajar, mempertahankan watak Saladin. Namun demikian, poster ini ditukar kemudiannya, dan watak Saladin kemudiannya diletakkan di tengah.

Untuk Saladin: The Animated Series keluaran 2010, Syarikat animasi Young Jump telah mengambil alih pemibikinan animasi 3D daripada tangan Silver Antz. Kenyataan dalam laman webnya:

Young Jump was commissioned by the Multimedia Development Corporation (MDeC) Malaysia and Al Jazeera Children's Channel (Qatar) to produce 26 episodes of the series. The series was recently nominated for an International Emmy Award for 2011 under the Children and Young People category.

(Young Jump, 2014).

Young Jump telah ditugaskan oleh Perbadanan Pembangunan Multimedia (MDeC) Malaysia dan Saluran Kanak-Kanak Al Jazeera (Qatar) untuk menghasilkan 26 episod siri ini. Siri ini juga telah dicalonkan untuk anugerah Emmy Antarabangsa untuk tahun 2011 di bawah kategori Children and Young People (Young Jump, 2014).

Kajian ini menggunakan penanda (signifier) yang diambil daripada poster dan penerangan petanda (signified) meneliti pendekatan orientalisme yang dibawa oleh pengarah. Dapatan kajian mendapati bahawa pengarah dan produksi siri animasi Saladin: The Animated Series tidak mengekalkan pemaparan watak Saladin sebagaimana dalam filem animasi Saladin.

\section{Penggunaan Bahasa Sebagai Suatu Sistem Tanda Dalam Saladin: The Animated Series}

Teori Saussure (1986, hlm. 3) menerangkan bahawa bahasa merupakan satu sistem tanda dan prinsip ini tersusun dalam dua bahagian, iaitu signifier (penanda) dan signified (petanda). Menurus Saussure (1986, hlm. 3-4) lagi, bahasa merupakan suatu sistem tanda, dan setiap tanda kebahasaan pada dasarnya menyatakan suatu konsep dan suatu citra suara (sound image). Kajian ini meletakkan bahasa yang digunakan dalam siri animasi Saladin: The Animated Series (2010) sebagai signifier atau penanda dan konsep signified atau petanda dan penerangan penanda digabungkan dengan wacana orientalisme. 
White dan Winn (1999, hlm. 61) telah menulis hasil kajiannya yang bertajuk Islam, Animation and Money: The Reception of Disney's Aladdin in Southeast Asia berkenaan penerimaan rakyat Malaysia dan beberapa negara Asia Tenggara seperti Malaysia, Indonesia, Brunei, dan Singapura ke atas animasi Aladdin yang dikeluarkan oleh Walt Disney Incorporated pada musin bunga tahun 1995. Malaysia dipilih kerana negara ini antara negara Asia Tenggara yang mempunyai penduduk Islam yang besar. Kajian ini mengenai kontroversi kandungan Siri Animasi Aladdin dan penerimaannya di negara-negara Asia Tenggara. Filem animasi Aladdin dianggap menghina dan boleh menyinggung perasaan orang Arab khususnnya dan seterusnya umat Islam umumnya.

Pengkritik filem berpendapat Aladdin ialah sebuah filem stereotaip orang AfrikaAmerika atau Yahudi. Watak Jasmine dan Aladdin ialah watak utama, namun mereka bertutur bahasa Inggeris Amerika. Formula yang sama telah berlaku dalam Saladin: The Animated Series. Siri ini, walaupun dikeluarkan oleh MDeC (Malaysian Development Corporation), bahasa utamanya ialah bahasa Inggeris dan bahasa Arab. Walaupun pada mulanya terdapat beberapa siri awal (siri satu dan dua) yang dialih bahasa ke bahasa Melayu, tiada lagi alih bahasa dilakukan dalam bahasa Melayu selepas daripada dua episod tersebut. Bahasa Melayu hanya digunakan dalam bentuk sari kata. Maka lenggok bahasanya masih menuruti struktur bahasa Inggeris. Contoh yang boleh diambil daripada siri pertama Rising Star atau 'Bintang yang Semakin Terserlah', dalam babak 11.38:

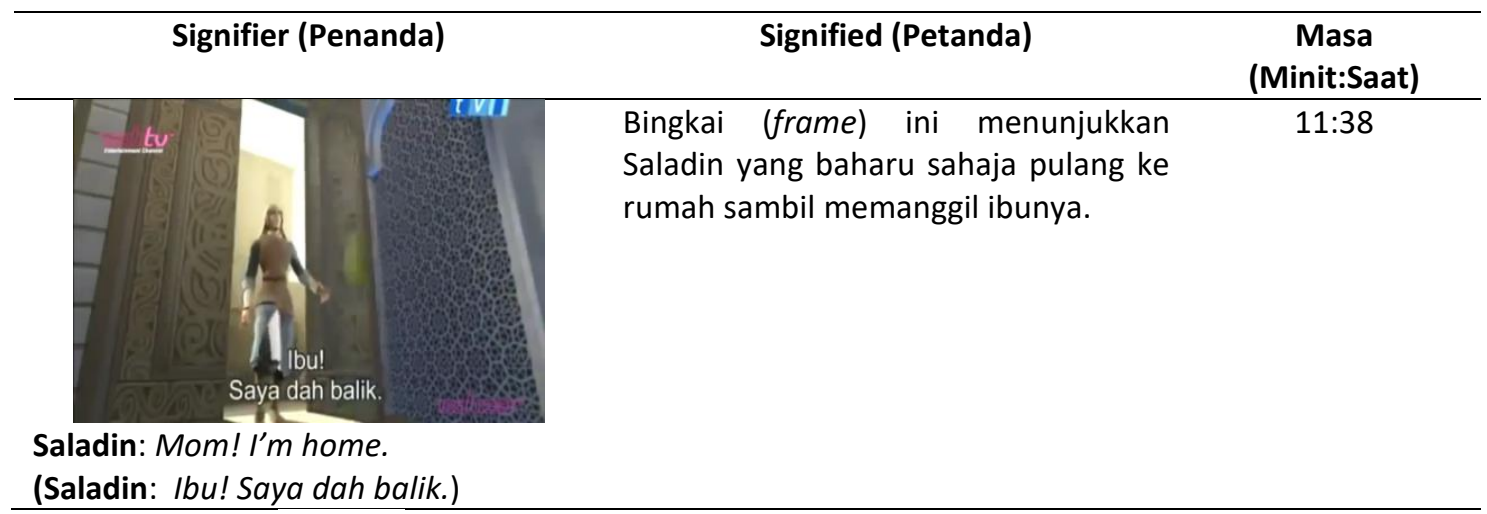

Sumber: Animated_Stories_of_Islam.nashbooky.com.mp4

Gambar 7: Saladin sebaik pulang ke rumah

Penanda daripada bingkai (frame) di atas menunjukkan berlakunya wacana orientalisme dalam penggunaan bahasa dan dapat disimpulkan bahawa bahasa utama yang digunakan dalam skrip siri animasi Saladin: The Animated Series ialah bahasa Inggeris. Skrip di atas merupakan direct translation atau terjemahan secara terus daripada bahasa Inggeris kepada bahasa Melayu:

$\begin{array}{lll}\text { Saladin } & : & \text { Mom! I'm home. } \\ \text { Saladin } & : & \text { Ibu! Saya dah balik. }\end{array}$

Mengapa sebuah cerita animasi tokoh Islam yang dilahirkan di sebuah negara yang majoritinya orang Islam, Malaysia, agama utamanya agama Islam dan bahasa kebangsaannya ialah bahasa Melayu, namun menggunakan bahasa Inggeris sebagai bahasa utama dalam penghasilan animasi ini, tidak bahasa Melayu dan tidak pula bahasa Arab? Penggunaan bahasa dalam animasi amat penting kerana bahasa itu menjadi pegangan keseluruhan pencitraan dan seharusnya sebagai sebuah animasi yang mengetengahkan tokoh Islam 
tersohor perlu dekat kepada Islam dan cara hidup Islam itu sendiri. Penggunaan salam seperti 'Assalamualaikum ibu' adalah kenyataan kepada cara hidup Islam yang seharusnya menjadi pegangan pihak produksi sewaktu melakarkan story line atau jalan cerita.

Formula wacana orientalisme yang sama yang telah digunakan sewaktu pembikinan Aladdin oleh pihak Disney. Watak Aladdin tidak menunjukkan cara hidup Islam, Islam itu hanya pada nama dan cara berpakaian untuk watak-watak lelaki sahaja. Watak Puteri Jasmine pula Islam itu hanya pada namanya sahaja dan tidak pada pakaiannya. Menurut White and Winn (1999, hlm. 61-62), pihak Disney telah mendapat keuntungan besar di Asia Tenggara. Dalam kajian analisis penerimaan yang dijalankan mereka, walaupun orang Arab menganggap animasi Aladdin bersifat perkauman, di Malaysia, Brunei, Indonesia, dan Singapura yang mempunyai populasi Islam yang besar, animasi ini diterima ramai. White dan Winn mendapati beberapa bantahan contohnya daripada Angkatan Belia Islam Malaysia (ABIM), tetapi bantahan daripada media dan awam adalah minimum. Menurut mereka lagi, orang Melayu ialah orang Islam dan bukan orang Arab. Masyarakat Islam Asia Tenggara tidak mengambil serius berkenaan pembikinan, kandungan, serta pemaparan dalam sesebuah animasi.

Pembuat filem Aladdin pula mengambil langkah untuk mengimbangi publisiti negatif yang melibatkan watak Aladdin dengan membuat gimik promosi besar-besaran. Pihak akhbar pula, menurut White and Winn (1999, hlm. 64), tidak memberikan sebarang tindak balas terhadap bantahan untuk mengharamkan Aladdin di Malaysia. Pihak akhbar lebih bergantung pada promosi galakan menonton dan sumber kewangan yang datang daripada sumber pengiklanan. Pihak kerajaan pula menyedari bahawa risiko pengharaman filem animasi Aladdin jauh lebih besar daripada memperoleh apa-apa manfaat daripada pengharaman tersebut. White dan Winn menyimpulkan bahawa walaupun pengamalan Islam adalah sangat kuat di Asia Tenggara, pegangan itu tidak dapat menyaingi kecintaan kepada wang dan penyanjungan kepada animasi Disney (White \& Winn, 1999, hlm. 61-78).

Dalam siri animasi Saladin: The Animated Series (2010), watak utama seperti Saladin, Duncan, Tarik, Anisa menggunakan bahasa Inggeris yang tinggi dan hanya watak-watak pipih seperti Saudagar Mustafa, Darwish, dan beberapa watak sampingan yang menggunakan bahasa Inggeris yang mempunyai aksen Arab. Dalam animasi, secara umumnya fenomena Kartun Disney memiliki stereotaip etnik dan nasionalis sebagaimana yang dinyatakan oleh Jonathan Rosenbaum pada tahun 1980 dalam bukunya yang bertajuk Submerged Nationalistic Propaganda, bahawa sejak tahun 1940-an lagi pengusaha filem animasi menggunakan stereotaip yang sama. Rosenbaum memberikan contoh animasi Pinocchio yang diterbitkan pada tahun 1940, watak protagonis Pinocchio menggunakan aksen bahasa Inggeris Amerika dan watak antagonis pula menggunakan aksen Inggeris Itali.

\section{KESIMPULAN}

Dalam kajian ini dapat disimpulkan bahawa pengarah siri animasi Saladin: The Animated Series telah memanipulasi tajuk siri ini dengan mengubah atau membaratkan nama Salahuddin menjadi Saladin. Seterusnya, perubahan dalam poster menunjukkan terdapat unsur penolakan daripada pemaparan Salahuddin al-Ayubi yang menggambarkan seorang tokoh Islam sehingga membawa kepada pemaparan watak Saladin yang mirip watak Disney. Watak Saladin telah dipergunakan secara simbolik oleh pengarah yang membawa pengaruh orientalis dalam animasi ini. Kesalahan penyesuaian ini telah mewujudkan kekeliruan bukan sahaja imej Salahuddin malahan pada agama Islam yang dipegang olehnya kerana hampir tiada unsur Islam yang dipaparkan dalam siri ini. 
Edward Said dalam gagasan Orientalisme, mengkritik pihak penjajah (Barat) menggunakan strategi dan praktik kolonialisme dalam bentuk baharu yang membawa orang Timur mengenali kehidupan yang lebih canggih dan moden. Orientalis menggunakan elemen penjajahan baharu dengan mengeksploitasi pelbagai sistem seperti ekonomi dan politik, sehingga mereka berjaya menemukan formula baharu untuk menjajah bangsa Timur melalui penjajahan dalam bentuk pengetahuan (Said, 2001).

Seterusnya, dalam proses penjajahan secara halus terhadap negara-negara Islam ini Azhar Abdul Rahman (2003, hlm. 71-79) bersependapat dengan Yusuf Qardhawi, dalam kajiannya 'Pengaruh Pemikiran Orientalis terhadap Pendidikan Islam di Malaysia'. Azhar juga menyatakan bahawa orientalis bermatlamat untuk menguasai pemikiran dan cara berfikir umat Islam sejak kanak-kanak Muslim ini masih kecil. Proses ini adalah bagi melahirkan generasi yang mengagumi dan mencontohi tamadun Barat. Sistem pendidikan Barat diserap masuk oleh misionari yang kemudiannya, menyelaraskan buku teks, kurikulum, malahan guru-guru yang dilahirkan daripada universiti-universiti di Barat yang telah diserap dengan pemikiran sekular supaya dapat ditanam dalam minda anak-anak. Golongan berfahaman sekular ini akan membentuk generasi yang memisahkan agama dengan kehidupan seharihari.

BIODATA

Izra Inna binti Md Idris ialah graduan PhD Pengajian Media di Jabatan Pengajian Media dan Komunikasi, Fakulti Sastera dan Sains Sosial, Universiti Malaya. Bidang pengkhususan beliau ialah kajian animasi, orientalism, dan intertekstualiti. E-mel: izrainna@gmail.com

Mohamad Saleeh bin Rahamad@Ahamad ialah pensyarah kanan di Jabatan Pengajian Media dan Komunikasi, Fakulti Sastera dan Sains Sosial, Universiti Malaya. Bidang Pengkhususan beliau ialah kajian oksidentalism, poskolonial, orientalism, kritikan sastera, seni dan budaya, penulisan kreatif cerpen, novel, puisi, sastera perbandingan, novel sejarah, kajian teks sastera, teori sastera, pangajian budaya, penguasaan Bahasa Melayu dan penulisan Bahasa Melayu. E-mel: saleeh334@gmail.com

Md Azalanshah bin Md Syed ialah ketua jabatan di Jabatan Pengajian Media dan Komunikasi, Fakulti Sastera dan Sains Sosial, Universiti Malaya. Bidang engkhususan beliau ialah Skrin dan Budaya Media (Produksi skrin dan drama televisyen), Etnografi penonton dan budaya popular. E-mel: azalan@um.edu.my 


\section{RUJUKAN}

Al-Quran Tajwid dan Terjemahan. Resam Uthmani Bahasa Melayu. Maghfirah Pustaka.

Abdul Malik Munip. (2003, Julai 29). Sebab Barat tidak boleh terima Islam (bahagian akhir). Utusan Malaysia.

Abdul Mun'im Al-Hasyimi. (2007). Para penakluk: Kisah para panglima Muslim menaklukkan dunia [Abdurrochim \& Hassan Barakuan, Terj.]. Akbar Media Eka Sarana.

Anuar Nor Arai. (1996). Teori dan kritikan filem: Internal composition of the close-up, movements of camera, duration, objective-subjective, close-up. Jabatan Media dan Komunikasi Universiti Malaya.

Azhar Abdul Rahman. (2003). Pengaruh pemikiran Orientalis terhadap pendidikan Islam di Malaysia: Suatu kajian mengenai sumber-sumber sejarah Islam di Malaysia [Tesis kedoktoran Jabatan Sejarah dan Tamadun Islam Bahagian Pengajian Usuluddin, Akademi Pengajian Islam, Universiti Malaya, Kuala Lumpur].

Azhar Wahid. (2011). Hegemoni intelektual kolonialisme dalam novel Melayu. Jurnal Melayu, 6, 169-185.

Barthes, R. (1964). Elements of semiology. Hill and Wang.

Barthes, R. (1988). The semiotics challenge. Hill and Wang.

Benda, H. J. (1972). Christiaan Snouck Hurgronje and the foundation of Dutch Islamic policy in Indonesia. In H. J. Benda (Ed.), Continuity and change in Southeast Asia: Collected Journal Articles of Harry J. Benda. Yale University Southeast Asia Studies.

Betulkan Balik Fakta Animasi Saladin. (2011). Home [Facebook page]. Facebook. https://www.facebook.com/Betulkan-balik-fakta-animasi-Saladin

Bristow, S. (Pengarah). (2010). Saladin: The animated series [Siri animasi]. Koridor Raya Multimedia (MSC).

Chandler, D. (2002). Semiotics: The basics. Routledge.

Colapietro, V. M., \& Olshewsky, T. M. (1996). Peirce's doctrine of signs. Teory, applications, and connections. Berlin: Division of Walter \& Gruyer \& Co.

Eco, U. (1979). A theory if semiotics. Indiana University Press.

Ed-Din, B. (2007). The life of Saladin: What befell Sultan Yusuf (Salah Ed-Din) (1137-1193 A.D.). Adam Publishers \& Distributors.

Engku Ahmad Zaki Engku Alwi. (2017). Gerakan orientalisme di Malaysia. Jurnal Peradaban,

2, 67-77. https://ejournal.um.edu.my/index.php/ADAB/article/view/7794

Fiske, J. (1990). Introduction to communication studies (2nd ed.). Routledge.

Gil, M. (1997). A history of Palestine 634-1099 (terj. Ethel Broido). Cambridge University Press. Hart, M. H. (1978). The 100: A ranking of most influential person in history. Hart Pub. Co.

Hassan Abdul Muthalib. (2008). Sejarah perkembangan animasi tempatan. Aswara.

Izra Inna Md Idris, Mohamad Saleeh Rahamad@Ahamad, \& Md Azalanshah Md Syed. (2017).

Saladin: The animated series sebagai wacana orientalisme. Jurnal Pengajian Media Malaysia, 19(1\&2,), 1-22.

Lane-Poole, S. (1906). Saladin and the fall of the Kingdom of Jerusalem. G.P. Putnam's Sons. Loomba, A. (1998). Colonialism/ Postcolonialism. Routledge.

M. Fazmi Hisham, Zairul Anuar Md Dawam, \& Imelda Ann Achin. (2019). Analisis semiotik watak dalam filem "Terbaik dari Langit". International Journal of Heritage, Art and Multimedia, 2(5), 124-144. http://www.ijham.com/PDF/IJHAM-2019-05-06-10.pdf

Mahmud Hamdi Zaqzuq, Mudasir Rosder, \& Che Yusoff Che Mat. (1989). Orientalisme: Kesan pemikirannya terhadap tamadun Islam. Dewan Bahasa dan Pustaka. 
Mana Sikana. (2013). Berdiri di akar diri. Kritikan sastera Melayu pascamoden. Institut Terjemahan dan Buku Malaysia.

Metz, C. (1995). Film language: A semiotics of the cinema. The University of Chicago Press.

Mohamad Sofee Razak. (2009). Serangan Orientalis ke atas pemikiran umat Islam. mohamadsofee. https://mohamadsofee.blogspot.com/2009/01/serangan-orientaliske-atas-pemikiran.html

Mohammad Redzuan Othman. (2003). Menyahut panggilan Kaabah: Sejarah pemergian orang melayu ke tanah suci dan kepentingannya kepada orang Melayu sebelum Perang Dunia Ke-II. Jurnal Usuluddin, 18, 175-198.

Mohd Farhan Abd Rahman. (2014). Pandangan R. O. Winstedt terhadap undang-undang Islam di Tanah Melayu [Tesis Sarjana Bahagian II, Jabatan Fiqh dan Usul, Akademi Pengajian Islam, Universiti Malaya].

Mohd Fikri Che Hussain. (2011). Awas ancaman Orientalis kepada kita. Karya Bestari Sdn. Bhd. Mohd Roslan Mohd Nor, \& Nor Shakila Mohd Noor. (2012). Salahuddin Al-Ayubi dalam menangani masyarakat Kristian di Islamic Jerusalem dan Palestin. Jurnal Usuluddin, 35(Januari-Jun), 81-98.

Mudjiono, Y. (2011). Kajian semioka dalam film. Jurnal IImu Komunikasi, 1(1), 125-138. http://jurnalfdk.uinsby.ac.id/index.php/JIK/article/view/101

Nilan, P. (2008). Muslim media and youth in globalizing Southeast Asia. In Kim, Y. (Ed.), Media consumption and everyday life in Asia (pp. 45-58). Routledge.

Nor Ain Matnoh, \& Zairul Anuar Md. Dawam. (2016). Simbolisme watak dan perwatakan berdasarkan konteks sosiobudaya masyarakat dalam filem Ola Bola (2016). e-Bangi, 16(6), 1-13.

Noriza Daud. (2004). Semiotik daripada perspektif Islam: Konsepsi lambang pantun warisan rakyat [Tesis Sarjana, Universiti Malaya].

Rosenthal, F. (2007). Knowledge Triumphant: The concept of knowledge in Medieval Islam. Brill.

Silver Antz. (2014). https://www.silver-ant.com/

Said, E. W. (1978). Orientalism: Western conceptions of the orient. Penguin Group.

Said, E. W. (2001). Power, politics, and culture: Interviews with Edward W. Said. Random House, Inc.

Saladin Convoy. (2008, Januari 2). Animasi Saladin - Indah khabar dari rupa? http://saladinconvoy.blogspot.com/2008/01/animasi-saladin-indah-khabar-darirupa.html

Sartre, J. P. (2001). Colonialism and neo-colonialism (Heddour, A., Brewer, S., \& McWilliams, T., Trans.). Routledge.

Saussure, F. d. (1986). Course in general linguistics (Bally, C., Sechehaye, A., \& Riedlinger, A. Eds., Harris, R., Trans.). Open Court.

Shamsul Amri Baharuddin. (2000). Ilmu kolonial dan pembinaan fakta mengenai Malaysia. DIm. Rahimah Abdul Aziz (pnyt.), Masyarakat, budaya dan perubahan. Penerbit Universiti Kebangsaan Malaysia.

Sobur, A. (2006). Semiotika komunikasi (Pengantar Yasraf Amir Piliang). PT Remaja.

Sujawoto, F. A. (2012). Citra Indonesia di dunia internasional melalui fotografi: Kajian kritis atas orientalisme hubungan internasional. Jurnal Studi Hubungan Internasional, 2(2), 118-141.

Syed Alwi Alatas. (2015). Biografi agung Salahuddin Al-Ayyubi. Karangkraf.

Umar, A. M. (1978). Orientalisme dan studi tentang Islam. Bulan Bintang. 
White, T. R., \& Winn, J. E. (1999). Islam, animation, and money: The reception of Disney's Aladdin in Southest Asia. In Lent, A. J. (Ed.), Themes and issues in Asian cartooning: Cute, cheap, mad, and sexy (pp. 61-76). Bowling Green State University Popular Press. Wibowo, I. S. W. (2013). Semiotika komunikasi - Aplikasi praktis bagi penelitian dan skripsi komunikasi (Edisi 2). Mitra Wacana Media.

Young Jump. (2014). Saladin 2008-2012. 